\title{
Main risk factors for diabetic foot
}

\author{
Marília Klein Reis", Júlia Scaravelli Mario, Mari Cassol Ferreira \\ From 20th Brazilian Diabetes Society Congress \\ Porto Alegre, Brazil. 11-18 November 2015
}

\section{Background}

Diabetic foot is a chronic complication of diabetes mellitus (DM) that may manifest as neuropathy, vasculopathy, osteoarticular involvement and infection. Foot injuries are among the most serious and costly complications of diabetes. Foot care programs can reduce the occurrence of injuries by $50 \%$.

\section{Objectives}

Assess the determinant risk factors of diabetic foot in DM patients assisted in the public health service of Chapecó-SC.

\section{Materials and methods}

Descriptive, cross-sectional study evaluated 130 diabetics type 1 and 2, over 18 yrs. old. The survey instrument adapted from "Rastreamento e avaliação precoce dos fatores de risco e prevenção do pé diabético", developed by SBD/DF and Grupo de Pé Diabético do Brasil, was applied to analyze neuropathic symptoms, feet clinical inspection, loss of protective sensation (LPS), peripheral arterial disease (PAD), ulcers, amputation and risk classification - 0: without LPS and PAD, 1: presence of LPS \pm deformities, 2: $\mathrm{PAD} \pm \mathrm{LPS}, 3$ : previous ulcers and/or amputation.

\section{Results}

Samples evaluated showed $99.2 \%$ of DM patients had DM2, $70 \%$ female, age $64.68 \pm 11.45$ yrs. old, disease duration $10.4 \pm 8.5$ yrs. and $17.7 \%$ of insulin users. Mean HbA1c was $8.02 \pm 2.19 \%$. Neuropathic symptoms were reported by $75.3 \%$ of patients, predominantly burning, numbness or tingling. The most prevalent clinical findings were dry skin, cracks or fissures (76.2\%), ungueal mycosis (33.8\%) and calluses (31.5\%). Inappropriate footwear use was seen in $74.6 \%$ of subjects. LPS was found in $28.5 \%$, and $73.3 \%$ of these had HbA1c>7\%

* Correspondence: marilia.kr@unochapeco.edu.br

Universidade Comunitária da Região de Chapecó, Chapecó, Brazil $(\mathrm{p}=0.069)$. LPS was detected in $80 \%$ of patients who had previous ulcers $(\mathrm{p}=0.023)$. The majority $(75 \%)$ of patients with involvement of thin fibers (burning or pain and/or thermal sensitivity decreased) had diabetes for less than 10 yrs., which is shown as a premature injury. While in $52,1 \%$ of patients with damage in thin+thick fibers (thin fiber+irregular monofilament exam and/or decreased vibratory sensation) had more than $10 \mathrm{yrs}$. of disease $(\mathrm{p}=0.031)$. PAD signals were observed in $20 \%$ of the sample. Regarding the risk classification, $57.7 \%$ were classified as risk $0,20.8 \%$ risk $1,16.9 \%$ risk 2 and $4.6 \%$ risk 3 .

\section{Conclusion}

Data confirms the impact of timing in diabetes evolution and uncontrolled glycaemia, also shows the onset of thin fibers signs of neuropathy occurs early before the LPS, serving as a warning for diagnosis and treatment in this evolution phase of peripheral neuropathy, which is the main risk factor for diabetic foot.

Published: 11 November 2015

doi:10.1186/1758-5996-7-S1-A26

Cite this article as: Reis et al:: Main risk factors for diabetic foot. Diabetology \& Metabolic Syndrome 2015 7(Suppl 1):A26.

Submit your next manuscript to BioMed Central and take full advantage of:

- Convenient online submission

- Thorough peer review

- No space constraints or color figure charges

- Immediate publication on acceptance

- Inclusion in PubMed, CAS, Scopus and Google Scholar

- Research which is freely available for redistribution 